\title{
Assessment of agricultural efficiency and yield gap for soybean in the Brazilian Central Cerrado biome
}

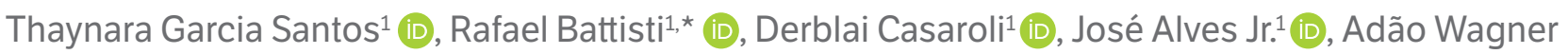 \\ Pêgo Evangelista ${ }^{1}$ (D) \\ 1. Universidade Federal de Goiás - Escola de Agronomia - Departamento de Engenharia de Biossistemas - Goiânia (GO), Brazil. \\ Received: Aug. 7, 2020 | Accepted: Jan. 25, 2021 \\ Section Editor: Gabriel Constantino Blain \\ *Corresponding author: battisti@ufg.br \\ How to cite: Santos, T. G., Battisti, R., Casaroli, D., Alves Junior, J., Evangelista, W. P. (2021). Assessment of agricultural efficiency and yield gap \\ for soybean in the Brazilian Central Cerrado biome. Bragantia, 80, e1821. https://doi.org/10.1590/1678-4499.20200352
}

\begin{abstract}
Soybean is the main crop grown in Brazil and is important to quantify the capacity of increase in yield by crop production intensification and management. This study aims to quantify yield gap and agricultural efficiency (AE) for soybean in Central Cerrado biome, Brazil. Yield gap by management $\left(Y_{M G}\right)$ and water deficit $\left(Y G_{W D}\right)$ and $A E$ and climate efficiency $(C E)$ were calculated based on potential (PoY), attainable (AtY) and actual (AcY) yields. Potential yields and AtY were simulated for the main sowing date, ranging from Oct 11 to Nov 01, using the agroecological zone crop model, from 1980/81 to 2016/17 growing seasons. The sites were Rio Verde (GO), Cristalina (GO), Barreiras (BA) and Peixe (TO). Actual yield was obtained from official statistics for each site. Agricultural efficiency rate for this period and its relationship with CE were analyzed. The $Y_{G_{M G}}$ were 4,345, 3,446, 4,531 and 2,649 kg $\cdot \mathrm{ha}^{-1}$ for Rio Verde, Cristalina, Peixe and Barreiras, respectively. Barreiras had a higher $\mathrm{YG}_{\mathrm{WD}}$ when compared with other sites, reaching a mean of $6,526 \mathrm{~kg} \cdot \mathrm{h} \mathrm{a}^{-1}$. However, Barreiras had a higher $\mathrm{AE}(51 \%)$, indicating that crop management applied in this region can explore the environmental conditions more than other sites. Agricultural efficiency showed an increasing rate from 0.70 to $1.21 \%$ per year, while the relation between AE and CE fitted an exponential negative function, by which higher water volume available reduced $A E$. Thus, it is possible to double soybean yield through improvements in management based on AtY $\left(7,409 \mathrm{~kg} \cdot \mathrm{ha}^{-1}\right)$ and AcY $\left(3,260 \mathrm{~kg} \cdot \mathrm{ha}^{-1}\right)$ in Central Cerrado biome, Brazil.
\end{abstract}

Key words: Glycine max L., potential yield, agricultural management, agriculture intensification, crop simulation model.

\section{INTRODUCTION}

Soybean is the main crop in Brazil, having 36 million hectares cultivated in the 2018/19 growing season, producing a total of 115 million tons, resulting in a mean actual yield (AcY) of 3,206 kg.ha-1 (CONAB 2020). This AcY is about half of yield observed in the best farm fields in Brazil (Battisti et al. 2018). The authors verified that soybean yield at farm level reached more than 5,000 $\mathrm{kg} \cdot \mathrm{ha}^{-1}$, when evaluated 200 farm fields across Brazil. These levels are similar as those the Global Yield Gap Atlas reported as a potential yield for soybean in Brazil (GYGA 2020).

The soybean production is driven to a constant increase in demand due to global population increase, associated with the multiple uses of this crop, such as human and animal feed and biodiesel production (Wu et al. 2018). The main alternative to maintain the soybean supply is to intensify production per area (Davis et al. 2016), thus reducing pressures over natural areas, as Cerrado biome.

The potential of production can be quantified through the interaction between crop, management efficiency and local climate (Sentelhas et al. 2015). Management efficiency can be quantified using the index of agricultural efficiency (AE) (Battisti et al. 2012). It defines the level of intensification in a site and the yield of farmers based on the yield the crop can reach considering environmental conditions at farm field (weather and soils). Agricultural efficiency is obtained through the relation between AcY and attainable yield (AtY). Actual yield is obtained from farmers plots or at a regional level. 
Attainable yield is estimated using crop growth models. The first step is to quantify the potential yield (PoY) considering solar radiation, air temperature, photoperiod and soybean genotype. Then, PoY is penalized by water deficit considering the crop phase-sensitive and relative evapotranspiration (Doorenbos and Kassam 1994; Pereira et al. 2002; Sentelhas et al. 2015). Climate efficiency (CE) is obtained from the relation between AtY and PoY, representing the effects of water deficit on yield (Battisti et al. 2013).

The hypothesis of this study is that soybean $\mathrm{AcY}$ can increase by improving AE. It is essential to quantify this improvement capacity to support the soybean supply capacity through intensification of production in local weather conditions. Thus, the study aims to (1) estimate the PoY and AtY using a crop growth model calibrated for high yield level, (2) quantify yield gap due to water deficit $\left(\mathrm{YG}_{\mathrm{WD}}\right)$ and management $\left(\mathrm{YG}_{\mathrm{MG}}\right)$, (3) quantify the historical progress and current $\mathrm{AE}$ and (4) analyze the relation between $\mathrm{AE}$ and $\mathrm{CE}$ for soybean in Central Cerrado biome, Brazil.

\section{MATERIAL AND METHODS}

The investigation was developed for four selected sites that had a high soybean production intensity among county located in

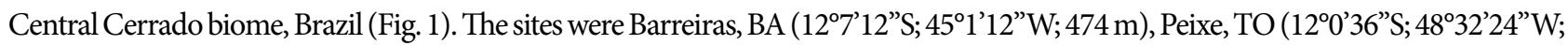

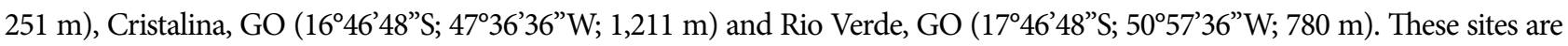
located and representative of the Brazilian Cerrado, a biome with an Aw climate (tropical zone with dry winters) (Alvares et al. 2013).

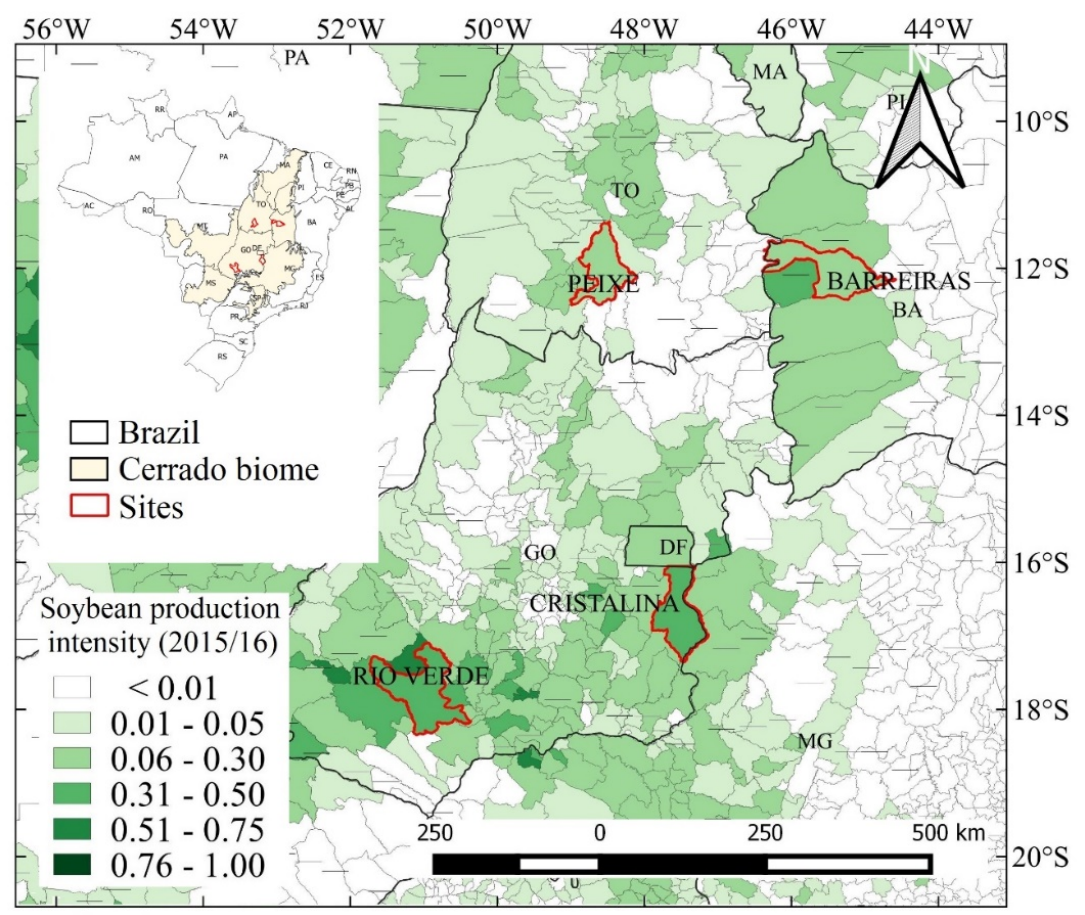

Figure 1. Soybean production intensity and sites considered in the quantification of AE in Central Cerrado biome, Brazil. Soybean production intensity was obtained by dividing the cultivated area of soybean by county area. Data were obtained from IBGE (2019). The smaller figure in the up-left corner is the map of Brazil, indicating the sites and the Cerrado biome.

The AtY was obtained considering the main sowing dates in each region following the agricultural crop zoning (MAPA 2019). The yield was simulated considering sowing on Nov. 1 in Barreiras, BA; on Oct. 11 in Cristalina, GO; Oct. 21 in Peixe, TO; and on Oct. 11 in Rio Verde, GO. Weather data were obtained from Xavier et al. (2015) for the period between 1980 and 2015 and from INMET (2019) between 2016 and 2017. The weather data obtained daily were air temperature, solar radiation, rainfalls, relative humidity and wind speed. 
The first step was to obtain the PoY using the agroecological zone crop model (Doorenbos and Kassam 1994; Pereira et al. 2002; Battisti et al. 2017; Battisti et al. 2018), using Eqs. 1, 2 and 3. Microsoft Excel software was used to perform the yield simulation. This crop model had a relative mean absolute error and Willmott $d$ index of $17 \%$ and 0.91 and $28 \%$ and 0.53 , respectively, for soybean after calibration and evaluation, being widely used in Brazil for soybean yield simulation (Battisti et al. 2017; Battisti et al. 2018).

$$
\begin{gathered}
P o Y=\sum_{i=1}^{n}\left[\frac{\mathrm{PPBp}_{\mathrm{i}} * \mathrm{C}_{\mathrm{IAF}_{i}} * \mathrm{C}_{\mathrm{R}_{i}} * \mathrm{C}_{\mathrm{C}}}{(1-0.01 * \mathrm{U} \%)}\right] \\
P P B c_{i}=\left[\left(107.2+8.604 * \mathrm{Qo}_{i}\right) * \mathrm{CTc}_{i} * \frac{\mathrm{n}_{i}}{\mathrm{~N}_{i}}\right] \\
P{ } n_{i}=\left[\left(31.7+5.234 * \mathrm{Qo}_{i}\right) * \mathrm{CTn}_{i} *\left(1-\frac{\mathrm{n}_{i}}{\mathrm{~N}_{i}}\right)\right]
\end{gathered}
$$

where: PoY is the potential yield $\left(\mathrm{kg} \cdot \mathrm{ha}^{-1}\right)$; PPBp is the gross dry matter produced daily (i) for a standard crop with leaf area index $(\mathrm{LAI})=5$ under clear $(\mathrm{PPBc})$ and cloudy $(\mathrm{PPBn})$ sky $\left(\mathrm{kg} \cdot \mathrm{ha}^{-1} \cdot\right.$ day $\left.^{-1}\right) ; \mathrm{C}_{\mathrm{IAF}}$ is an index to adjust the actual leaf area index from a standard of 5 and this was obtained by dividing the actual LAI by 5 and the LAI curve was obtained from Battisti et al. (2018); $C_{R}$ is an index to adjust crop respiration in function of air temperature, being 0.5 and 0.6 for mean air temperature above and below $20^{\circ} \mathrm{C}$, respectively; $\mathrm{CC}$ is the harvest index with a value of 0.53 (Battisti et al. 2017); $\mathrm{U} \%$ is the final residual water in the grain (13\%); (i) is the number of days between sowing and physiological maturity and a mean of 125 days was considered (Battisti et al. 2017); Qo is the global extraterrestrial solar radiation (MJ.m ${ }^{-2} \cdot \mathrm{day}^{-1}$ ); cTc and cTn are adjusted based on air temperature for the clear and cloudy sky, respectively (Pereira et al. 2002); clear and cloudy sky were defined by the relation between $\mathrm{n}$ and $\mathrm{N}$, respectively, the effective hours of sunshine $\left(\mathrm{h} \cdot \mathrm{day}^{-1}\right)$ and the photoperiod $\left(\mathrm{h} \cdot \mathrm{day}^{-1}\right)$.

The AtY was obtained by subtracting the water deficit from the PoY using Eq. 4. The relative evapotranspiration per crop phase was used to quantify water deficit. Yield loss was calculated in functions of water deficit using the crop sensitivity index to water deficit (Ky).

$$
A t Y=P o Y \times \prod_{i=1}^{n}\left[1-K y_{i} *\left(1-\frac{E T a_{i}}{E T c_{i}}\right)\right]
$$

where: AtY is the attainable yield $\left(\mathrm{kg}_{\mathrm{ha}} \mathrm{ha}^{-1}\right)$; Ky is the yield response factor to water deficit for each crop phase (i), being establishment $=0.05$, vegetative growth $=0.15$, flowering $=0.40$, grain filling $=0.75$ and repining $=0.10$ (Battisti et al. 2017); ETa is the actual evapotranspiration obtained using daily water balance data from Thornthwaite and Mather (1955) adapted by Battisti et al. (2018) for change maximum water available to the crop in function of root growth, considering a soil with clay loam texture and a maximum available water to crop at maximum root depth of $75 \mathrm{~mm}$ (Battisti et al. 2018); ETc is the potential crop evapotranspiration obtained considering the reference evapotranspiration (ETo), obtained using the Penman-Monteith approach (Allen et al. 1998) and crop coefficient (Kc) (Battisti et al. 2018) daily; ETa and ETc were obtained considering the mean value for each crop phase (i) based on daily results.

Actual yield was obtained from IBGE (2019) official statistics. The data for mean yield is available for each county for a growing season. The period analyzed was from 1980/81 to 2016/17. Agricultural efficiency was obtained by Eq. 5 through the relation between AcY and AtY. Climate efficiency was obtained using Eq. 6 through the relation between AtY and PoY, representing the fraction of yield without water deficit that was obtained under rainfall conditions. The AtY was considered for each production system in rainfall conditions.

$$
\begin{aligned}
& A E_{i}=\frac{A c Y_{i}}{A t Y_{i}} \times 100 \\
& C E_{i}=\frac{A t Y_{i}}{P o Y_{i}} \times 100
\end{aligned}
$$


where: $\mathrm{AE}$ and $\mathrm{CE}$ are, respectively, the agricultural and climate efficiencies in \% for 37 (i) growing seasons, AcY is the actual yield obtained at a county level, AtY and PoY are, respectively, the attainable and potential yield obtained by the crop growth model.

Agricultural efficiency was adjusted using linear regression to obtain the slope curve for the period 1980/81 to 2016/17, which represents the increase in efficiency due to better management over time. The ratio between AE and CE was analyzed by fitting an adequate regression to verify the effects of water deficit on management efficiency. In this analysis, AE was obtained by adding technological tendency yield at AcY in the previous growing seasons from 2016/17, following the approach of Teixeira et al. (2019). The AcY rate was obtained by linear adjust, which was multiple by the number of years between the growing seasons and 2016/17, adding this value to AcY. For example, the adjusted AcY in 1980/81 was obtained by multiplying the rate by 37 years, plus the actual from 1980/81.

Potential yield, AtY, AcY and AE were characterized based on current technological level using the mean values from 2012/13 to 2016/17, using approach recommended by van Ittersum et al. (2013). The $\mathrm{YG}_{\mathrm{WD}}$ was obtained by the difference between the PoY and AtY. The $\mathrm{YG}_{\mathrm{MG}}$ was obtained by the difference between AtY and AcY considering the period 2012/13 to 2016/17. Potential yield, AtY, $\mathrm{YG}_{\mathrm{WD}}$ and $\mathrm{AE}$ were submitted to analysis of variance at $5 \%$ error probability, considering the experimental design of randomized blocks, where the sites $(n=4)$ were the treatments and the growing seasons were replicated, being 37 for PoY, AtY and $\mathrm{YG}_{\mathrm{WD}}$ and five for $\mathrm{AE}$. If the difference between treatments was significant, the treatments were compared by Tukey's test at $5 \%$ of probability. The analyses were performed using the software SASMAGRI (Canteri et al. 2001).

\section{RESULTS AND DISCUSSION}

The highest PoY was observed for Barreiras (BA) (Table 1). The value was $12,078 \mathrm{~kg} \cdot \mathrm{ha}^{-1}$, which was statistically different from the other sites. The sites Rio Verde, Peixe and Cristalina had PoY ranging from 11,075 to 11,169 kg.ha ${ }^{-1}$. Potential yield is the result of climate conditions, including solar radiation, air temperature and photoperiod, in interaction with the crop without considering water deficit (Sentelhas et al. 2015). In Barreiras (BA), around $8 \%$ higher solar radiation was observed during soybean cycle than other sites. The mean solar radiation was $18.89,18.49,18.95$ and $20.32 \mathrm{MJ} \cdot \mathrm{m}^{-2}$ day, respectively, for Rio Verde, Peixe, Cristalina and Barreiras.

Table 1. Analysis of variance, mean PoY, AtY and AcY and $Y_{W D}$ for soybean in the 1980/81 to 2015/16 growing seasons in four sites in Central Cerrado biome, Brazil.

\begin{tabular}{|c|c|c|c|c|c|}
\hline \multirow{3}{*}{ Factor } & \multirow{3}{*}{ D.F. } & \multicolumn{4}{|c|}{ M.Q } \\
\hline & & \multirow{2}{*}{ PoY } & \multirow{2}{*}{ AtY } & \multicolumn{2}{|c|}{$Y_{\mathrm{WD}_{\mathrm{W}}}$} \\
\hline & & & & $\mathbf{k g} \cdot \mathrm{ha}^{-1}$ & $\%$ \\
\hline Blocks & 36 & $880739^{* *}$ & $2123334^{\star \star}$ & $4624382^{* *}$ & $273^{* *}$ \\
\hline Sites & 3 & $8360708^{\star *}$ & $59832429^{* *}$ & $110704564^{\star *}$ & $6538^{* *}$ \\
\hline Residues & 108 & 147493 & 688719 & 976987 & 63 \\
\hline Total & 147 & & & & \\
\hline C.V. & & $3.38 \%$ & $11.20 \%$ & $24.97 \%$ & $12.02 \%$ \\
\hline \multirow{2}{*}{ Sites } & PoY & AtY & $\mathrm{AcY}^{2}$ & \multicolumn{2}{|c|}{$Y_{G_{W D}}$} \\
\hline & & $\mathbf{k g} \cdot \mathrm{ha}^{-1}$ & & $\mathbf{k g} \cdot \mathrm{ha}^{-1}$ & $\%$ \\
\hline Rio Verde (GO) & $11,169 \mathrm{~b}$ & $8,271 \mathrm{a}$ & 3,308 & $2,898 \mathrm{a}$ & $25 a$ \\
\hline Cristalina (GO) & 11,075 b & $7,616 \mathrm{~b}$ & 3,654 & $3,459 \mathrm{~b}$ & $31 b$ \\
\hline Barreiras (BA) & $12,078 \mathrm{a}$ & $5,552 \mathrm{c}$ & 2,832 & $6,526 c$ & $54 \mathrm{c}$ \\
\hline Peixe (TO) & $11,149 \mathrm{~b}$ & $8,196 a$ & 3,114 & $2,953 \mathrm{a}$ & $26 a$ \\
\hline
\end{tabular}


The AtY had higher values in Rio Verde (GO) and Peixe (TO): 8,271 and 8,196 kg.ha- ${ }^{-1}$, respectively (Table 1), which were statistically similar. Cristalina (GO) had intermediate AtY: 7,616 kg.ha-1. Barreiras (BA) had a lower value: $5,552 \mathrm{~kg} \cdot h \mathrm{~h}^{-1}$. In Barreiras (BA), the $\mathrm{YG}_{\mathrm{WD}}$ obtained the highest value, reaching a mean loss of $6,526 \mathrm{~kg} \cdot \mathrm{ha}^{-1}$, while Peixe (TO) and Rio Verde (GO) had the lowest $\mathrm{YG}_{\mathrm{wD}}$.

Sentelhas et al. (2015) observed a relative $\mathrm{YG}_{\mathrm{WD}}$ of 18, 24, 25 and $30 \%$ for Rio Verde (GO), Cristalina (GO), Peixe (TO) and Barreiras (BA), respectively. In this study, 25, 31, 26 and 54\% were observed, respectively. These differences between studied sites are associated with yield level and the reference used to calibrate the crop growth model, which affects the levels of yield gap. Lobell et al. (2009) discussed about the yield used as reference to estimate the yield gap. In these cases, the approach used was the same; however, Sentelhas et al. (2015) used yield from cultivars trial as reference from growing seasons between 2008 and 2011 (maximum yield below 6,000 kg.ha ${ }^{-1}$ ); while Battisti et al. (2018) used yield from soybean contest during growing seasons between 2014 and 2017, with yield level between 4,800 and $8,800 \mathrm{~kg} \cdot \mathrm{ha}^{-1}$. This yield gap range helped to create different scenarios of yield project by management improvement (Teixeira et al. 2019).

The maximum yield for soybean is a current concern; due to record yields in areas of soybean contest to be higher than the maximum yield observed in the field experiment. For example, in Brazil, the maximum yield observed in the yield contest was $8,800 \mathrm{~kg} \cdot \mathrm{ha}^{-1}$, while the mean AcY for farmers with AE and CE higher than $80 \%$ was 7,832 $\mathrm{kg} \cdot \mathrm{ha}^{-1}( \pm 879)$, representing 2,5\% of the evaluated areas (Battisti et al. 2018). La Menza et al. (2017) verified a maximum soybean yield of $6,500 \mathrm{~kg} \cdot \mathrm{ha}^{-1}$ in the environment with higher PoY in Argentina and the USA and to explore maximum yield associated with the use of irrigation and full nitrogen supply. Further, the divergence between studies for maximum yield suggested the need for further studies to clarify what would be the genetic yield potential of soybean in tropical conditions and how climate change will affect yield.

Losses by water deficit occur mainly by limiting the water availability during sensitivity phases, such as sowing-emergence, and between flowering and grain filling (Farias et al. 2009). Cultivars with a higher drought tolerance can be used in sites with higher water deficits (Battisti and Sentelhas 2015), such as Barreiras (BA). Root growth is an interesting trait, for it can be obtained through the improvement of chemical and physical soil characteristics (Battisti and Sentelhas 2017). Irrigation can be used to improve yield (Pilau et al. 2018; Justino et al. 2019), a condition that has already been used in Cristalina (GO) and Barreiras (BA) for other crops.

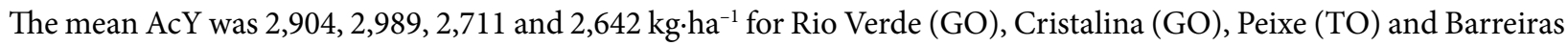
(BA), respectively (Fig. 2), considering the average of the last five growing seasons (from 2012/13 to 2016/17) (IBGE 2019). The highest value of AcY was 3,500 $\mathrm{kg} \cdot \mathrm{ha}^{-1}$, recorded in Rio Verde (GO) in the 2016/17 growing season (Fig. 2a). In this growing season, the climate conditions led to an AtY of over $8,000 \mathrm{~kg} \cdot \mathrm{ha}^{-1}$, resulting in a $\mathrm{YG}_{\mathrm{MG}}$ of $4,800 \mathrm{~kg} \cdot \mathrm{ha}^{-1}$. The results indicate a potential for yield improvement by using better crop managements. Thus, it is essential to identify the main limiting factors for yield (Battisti et al. 2018).

The lowest AcY occurred in Peixe (TO): 1,761 kg.ha-1 in the 2015/16 growing season (Fig. 2c). This same growing season obtained the lowest yield in Barreiras (BA): 2,220 kg.ha-1 (Fig. 2d). Yield gap management was 4,345, 3,446, 4,531 and 2,649 $\mathrm{kg} \cdot \mathrm{ha}^{-1}$ for Rio Verde (GO), Cristalina (GO), Peixe (TO) and Barreiras (BA), respectively (Fig. 2), considering the mean of the last five growing seasons. Barreiras (BA) had the lowest mean $\mathrm{YG}_{\mathrm{MG}}$, which is associated with lowest AtY by high water deficit. This site had a superior AE than the others. Agricultural efficiency was 51\% (Table 2), even with a lower AcY (Fig. 2d). This means that the crop management applied in this region could explore more the environmental conditions than other regions, including the interaction with climate (Radin et al. 2017; Hampf et al. 2020).

Agricultural efficiency was statistically similar in Rio Verde (GO) and Cristalina (GO), with means of 40 and $47 \%$, respectively (Table 2). Peixe (TO) had the lowest values of AE, with a mean of $38 \%$ in the last five growing seasons, ranging across growing seasons from 24 to $49 \%$, showing an interaction between management and weather conditions for farmers to explore the environment. The $\mathrm{AE}$ of $80 \%$ is a value reachable at the farmer level (Lobell et al. 2009), indicating that yield can increase between 29 and $42 \%$ in the analyzed region, considering the mean AE of the last five growing seasons. 

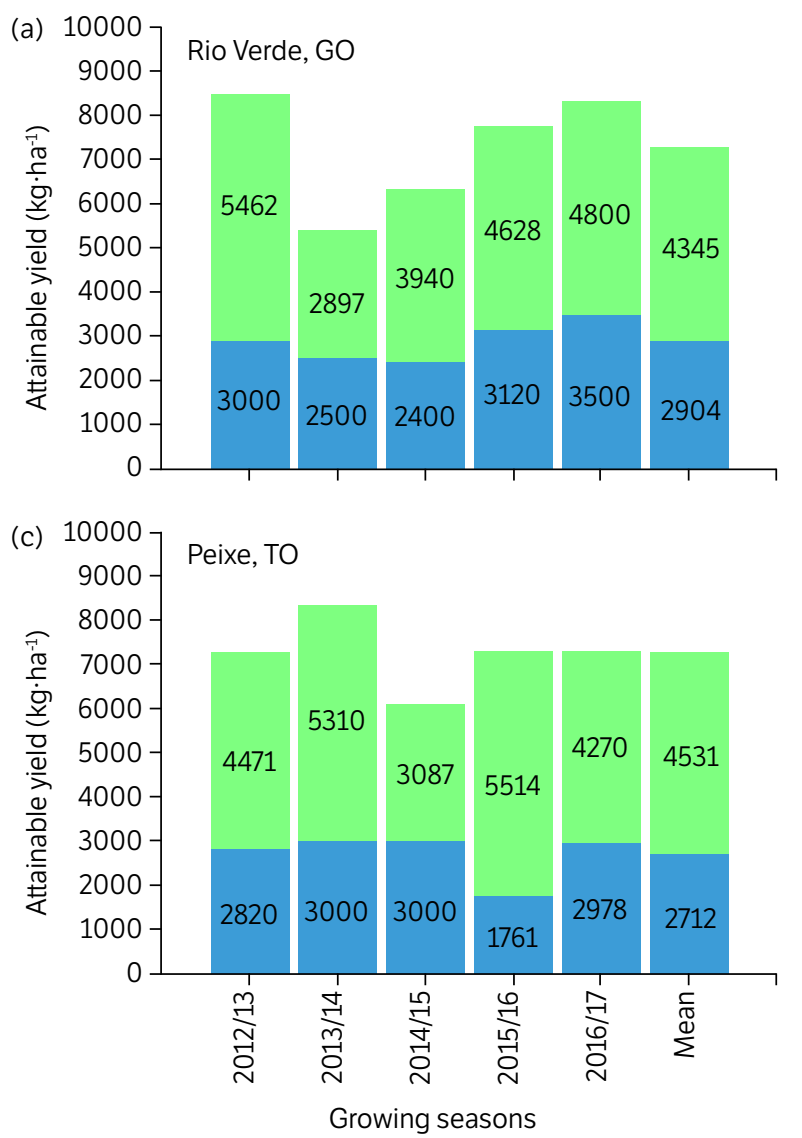

(b)

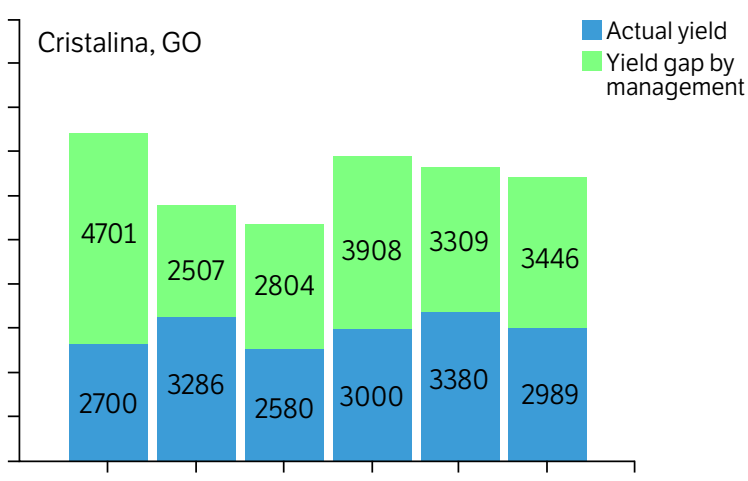

(d)

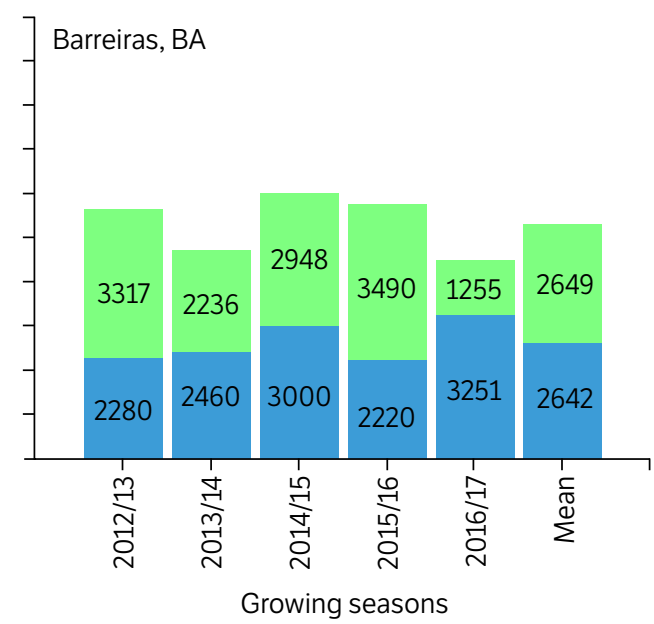

Figure 2. Actual yield and $\mathrm{YG}_{M G}$ for five growing seasons (from 2011/12 to 2015/16) and means for four sites in Central Cerrado biome, Brazil. Attainable yield is the sum between $A c Y$ and $Y_{M G}$.

Table 2. Analysis of variance (ANOVA) and AE from 2012/13 to 2016/17 for five sites in Central Cerrado biome, Brazil.

\begin{tabular}{|c|c|c|c|c|c|c|}
\hline Factor & \multicolumn{2}{|c|}{ D.F. } & \multicolumn{4}{|c|}{ M.Q } \\
\hline Blocks & \multicolumn{2}{|c|}{4} & \multicolumn{4}{|c|}{$168^{*}$} \\
\hline Sites & \multicolumn{2}{|c|}{3} & \multicolumn{4}{|c|}{$179^{*}$} \\
\hline Residues & \multicolumn{2}{|c|}{12} & \multicolumn{4}{|c|}{55} \\
\hline Total & \multicolumn{2}{|c|}{19} & & & & \\
\hline \multicolumn{3}{|l|}{ C.V. } & \multicolumn{4}{|c|}{$16.85 \%$} \\
\hline \multirow{2}{*}{ Sites } & \multicolumn{6}{|c|}{$A E(\%)$} \\
\hline & $2012 / 13$ & $2013 / 14$ & $2014 / 15$ & $2015 / 16$ & $2016 / 17$ & Mean $^{1}$ \\
\hline Rio Verde (GO) & 35 & 46 & 38 & 40 & 42 & $40 \mathrm{~b}$ \\
\hline Cristalina (GO) & 36 & 57 & 48 & 43 & 51 & $47 \mathrm{~b}$ \\
\hline Barreiras (BA) & 41 & 52 & 50 & 39 & 72 & $51 a$ \\
\hline Peixe (TO) & 39 & 36 & 49 & 24 & 41 & $38 c$ \\
\hline
\end{tabular}

"and "* are significant by ANOVA test at 5 and $1 \%$, respectively. ${ }^{1}$ Mean values followed by the same letter do not statistically differ by Tukey's test at a level of $5 \%$ of probability. 
Agricultural efficiency showed a rate of increase from 0.70 to $1.21 \% \cdot$ year $^{-1}$ from $1980 / 1981$ to $2016 / 17$ for the sites analyzed (Fig. 3). This increase is based on climate conditions for each growing season if actual management (used to calibrate the crop model) had been applied in all growing seasons. Rio Verde (GO), Cristalina (GO) and Peixe (TO) had a similar rate: around $0.70 \% \cdot y^{-1}{ }^{-1}$. This indicates that the management was similar in these sites. However, Barreiras (BA) showed a rate of $1.21 \% \cdot$ year $^{-1}$, almost the double than other sites, and AE reached $80 \%$ in the $2011 / 12$ growing season.

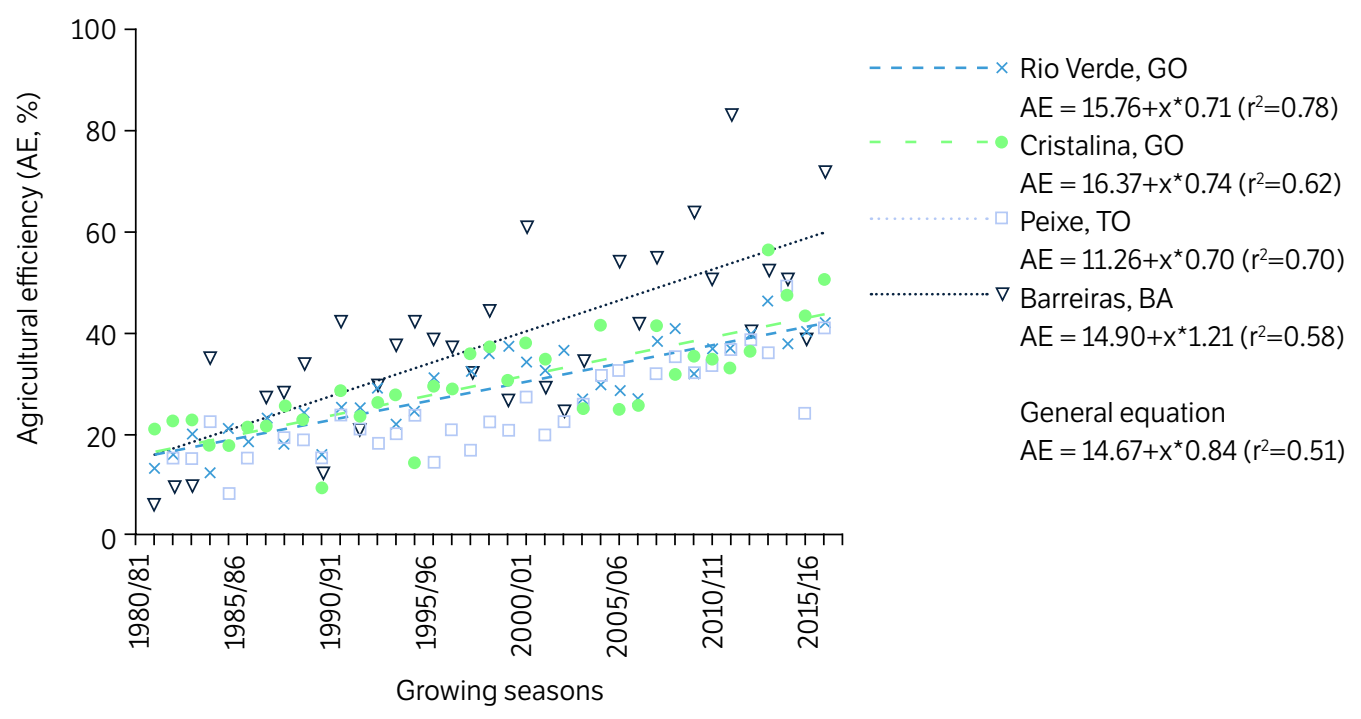

Figure 3. Agricultural efficiency from the $1980 / 81$ to $2016 / 17$ growing seasons for four sites in Central Cerrado biome, Brazil. In the equation, $x$ represents the number of the growing season from 1980/81 ( $b=1)$ to $2016 / 17(b=37)$. The equations had a significance level of $1 \%(p<0.01)$.

The increase in $\mathrm{AE}$ indicates that agricultural management has improved over time, including soil fertility (Battisti et al. 2018), use of better adapted cultivars (Zanon et al. 2015), improvement of soil management through no-tillage system (Cardoso et al. 2014) and better quality for sowing and harvest (Battisti et al. 2018). The production system and climate affected $\mathrm{AE}$ progress due to the interaction between crops, sowing dates required for soybean as a previous crop and residual fertilization. Cristalina (GO) and Rio Verde (GO) had a predominance of soybean, followed by maize in the off-season (Nóia Junior and Sentelhas 2019). Peixe (TO) had soybean as the main crop, not followed by crops due to a short rainfall period. However, Barreiras (BA) had soybean followed by cotton (IBGE 2019), where soybean can benefit from the higher fertilization volumes used for cotton.

The relation between AE (y) and CE (x) fitted an exponential negative function (Fig. 4). This indicates that farmers had higher $\mathrm{YG}_{\mathrm{MG}}$ during growing seasons in a lower water deficit, when AtY was higher. This tendency was observed for soybean (Merlos et al. 2015; Battisti et al. 2018), maize and wheat (Merlos et al. 2015), sugarcane (Dias and Sentelhas 2018) and eucalyptus (Elli et al. 2019), when yield gap was quantified. The lowest AE under the best CE indicates that limiting factors associated with crop management are more marked when water availability is higher (Fig. 4). For example, these includes higher pressure from diseases, such as soybean Asian rust (Del Ponte et al. 2006), less favorable conditions for management, leading to low quality of sowing, harvest and pest and disease control (Monteiro et al. 2014), lower nitrogen fixation due to soil saturation (Mason et al. 2018) and an inadequate adjustment of plant density to the climate during growing seasons that leading to plant lodging (Tagliapietra et al. 2018). These factors needs be analyzed experimentally to identify the yield gap weight and strategies to reduce yield losses under high CE. 


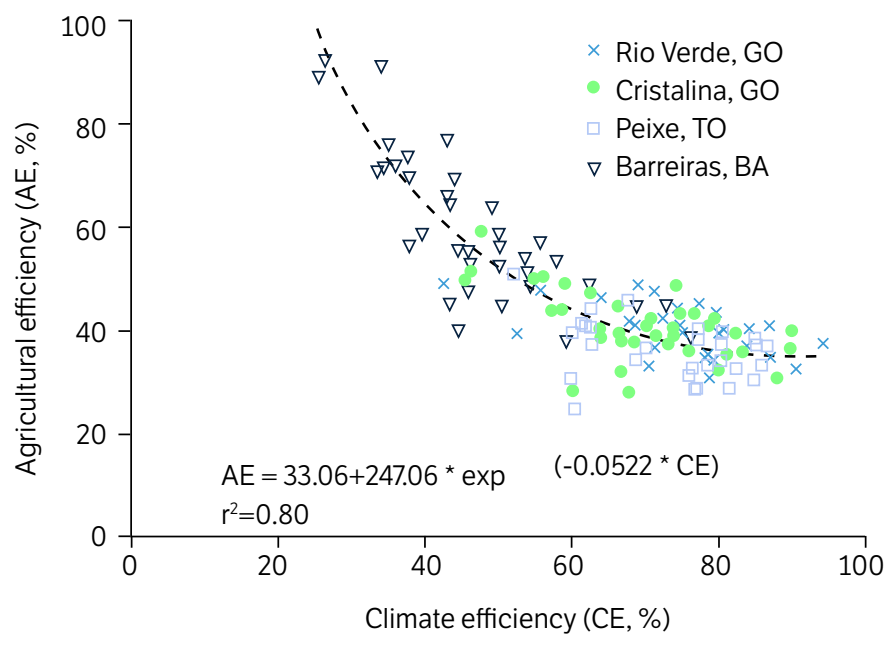

Figure 4. Relation between $\mathrm{AE}$ and $\mathrm{CE}$ for four sites and 37 growing seasons in Central Cerrado biome, Brazil.

\section{CONCLUSION}

Potential yield and AtY simulated for soybean crop show that water deficit reduces considerably the yield at different levels in Central Cerrado biome, Brazil. It is possible to double soybean yield through improvements in management based on the AtY and AcY observed in the sites.

There was a historical increase in AE of soybean, which is associated with improvement of crop management.

Agricultural efficiency decreased with the increase in climate efficiency, following an exponential negative regression. Improvements in crop management are needed to obtain a higher $\mathrm{AcY}$ in growing seasons with higher water availability.

\section{AUTHORS' CONTRIBUTION}

Conceptualization: Santos T. G., Battisti R. and Casaroli D.; Methodology: Battisti R.; Investigation: Santos T. G. and Battisti R.; Writing - Original Draft: Santos T. G. and Battisti R.; Writing - Review and Editing: Santos T. G., Battisti R., Casaroli D., Alves Jr. J. and Evangelista A. W. P.; Funding Acquisition: Alves Jr. J. and Evangelista A. W. P.; Supervision: Battisti R. and Casaroli D.

\section{DATA AVAILABILITY STATEMENT}

Data sharing is not applicable.

\section{FUNDING}

Conselho Nacional de Desenvolvimento Cientifico e Tecnológico

[https://doi.org/10.13039/501100003593]

Grant No 405740/2018-2 
Fundação de Amparo à Pesquisa do Estado de Goiás

[https://doi.org/10.13039/501100005285]

Grant No 201710267000520

\section{ACKNOWLEDGMENTS}

Not applicable.

\section{REFERENCES}

[CONAB] Companhia Nacional de Abastecimento. (2020). Acompanhamento de safra brasileiro - grãos: safra 2018/2019. Brasília: Companhia Nacional de Abastecimento. 2020. [Accessed Jun. 4, 2020]. Available at: https://www.conab.gov.br/info-agro/safras/graos/ [GYGA]. Global Yield Gap Atlas. (2020). Yield gap for soybean in Brazil. [Accessed Mar. 26, 2020]. Available at: http://www.yieldgap.org/ [IBGE] Instituto Brasileiro de Geografia e Estatística. (2019). Produtividade agrícola municipal. [Accessed Jun. 1, 2019]. Available at: https://sidra.ibge.gov.br/tabela/1612

[INMET] Instituto Nacional de Meteorologia. (2019). Banco de Dados Meteorológicos Para Ensino e Pesquisa (BDMEP). Inmet. [Accessed Mar. 18, 2019]. Available at: http://www.inmet.gov.br/projetos/rede/pesquisa/

[MAPA] Ministério da Agricultura, Pecuária e Abastecimento. (2019). Climate Risk Zoning. [Accessed Jul. 1, 2019]. Available at: http:// www.agricultura.gov.br/politica-agricola/zoneamento-agricola/

Allen, G. R., Pereira, L. S., Raes, D. and Smith, M. (1998). Crop evapotranspiration: guidelines for computing crop water requirements. Rome: FAO.

Alvares C. A., Stape, J. L., Sentelhas, P. C., Moraes, G., Leonardo, J. and Sparovek, G. (2013). Köppen’s climate classification map for Brazil. Meteorologische Zeitschrift, 22, 711-728. https://doi.org/10.1127/0941-2948/2013/0507

Battisti, R. and Sentelhas, P. C. (2015). Drought Tolerance of Brazilian Soybean Cultivars Simulate by a Simple Agrometeorological Yield Model. Experimental Agriculture, 51, 285-298. https://doi.org/10.1017/S0014479714000283

Battisti, R. and Sentelhas, P. C. (2017). Improvement of soybean resilience to drought through deep root system in Brazil. Agronomy Journal, 109, 1612-1622. https://doi.org/10.2134/agronj2017.01.0023

Battisti, R., Sentelhas, P. C. and Pilau, F. G. (2012). Eficiência agrícola da produção de soja, milho e trigo no estado do Rio Grande do Sul entre 1980 e 2008. Ciência Rural, 42, 24-30. https://doi.org/10.1590/S0103-84782012000100005

Battisti, R., Sentelhas, P. C., Pilau, F. G. and Wollmann, C.A. (2013). Eficiência climática para as culturas da soja e do trigo no estado do Rio Grande do Sul em diferentes datas de semeadura. Ciência Rural, 43, 390-396. https://doi.org/10.1590/S0103-84782013000300003

Battisti, R., Sentelhas, P. C. and Boote, K. J. (2017). Inter-comparison of performance of soybean crop simulation models and their ensemble in southern Brazil. Field Crop Research, 200, 28-37. https://doi.org/10.1016/j.fcr.2016.10.004

Battisti, R., Sentelhas, P. C., Pascoalino, J. A. L., Sako, H., Dantas, J. P. S. and Moraes, M. F. (2018). Soybean Yield Gap in the Areas of Yield Contest in Brazil. International Journal of Plant Production, 12, 159-168. https://doi.org/10.1007/s42106-018-0016-0

Canteri, M. G., Althaus, R. A, Virgens Filho, J. S., Giglioti, E. A. and Godoy, C. V. (2001). SASM-Agri - Sistema para análise e separação de médias em experimentos agrícolas pelos métodos Scott-Knott, Tukey e Duncan. Revista Brasileira de Agrocomputação, 1, $18-24$. 
Cardoso, R. A., Bento, A. S., Moreski, H. M. and Gasparotto, F. (2014). Influência da adubação verde nas propriedades físicas e biológicas do solo e na produtividade da cultura de soja. Semina: Ciências Biológicas e da Saúde, 35, 51-60. https://doi. org/10.5433/1679-0367.2014v35n2p51

Davis, K. F., Gephart, J. A., Emery, K. A., Leach, A. M., Galloway, J. N. and D'Odorico, P. (2016). Meeting future food demand with current agricultural resources. Global Environmental Change, 39, 125-132. https://doi.org/10.1016/j.gloenvcha.2016.05.004

Del Ponte, E. M., Godoy, C. V., Li, X. and Yang, X. B. (2006). Predicting Severity of Asian Soybean Rust Epidemics with Empirical Rainfall Models. Phytopathology, 96, 797-803. https://doi.org/10.1094/PHYTO-96-0797

Dias, H. B. and Sentelhas, P. C. (2018). Sugarcane yield gap analysis in Brazil-A multi-model approach for determining magnitudes and causes. Science of The Total Environment, 637-638, 1127-1136. https://doi.org/10.1016/j.scitotenv.2018.05.017

Doorenbos, J. and Kassam, A. H. (1994). Efeito da água no rendimento das culturas. Campina Grande: UFPB.

Elli, E. F., Sentelhas, P. C., Freitas, C. H., Carneiro, R. L. and Alvares, C. A. (2019). Assessing the growth gaps of Eucalyptus plantations in Brazil-Magnitudes, causes and possible mitigation strategies. Forest Ecology and Management, 451, 117464. https://doi.org/10.1016/j. foreco.2019.117464

Farias, J. R. B., Neumaier, N. and Nepomuceno, A. L. (2009). Soja. In J. E. B. A. Monteiro (Ed.), Agrometeorologia dos cultivos: o fator meteorológico na produção agrícola (p. 261-278). Brasília: INMET.

Hampf, A. C., Stella, T., Berg-Mohnicke, M., Kawohl, T., Kilian, M and Nendel, C. (2020). Future yields of double-cropping systems in the Southern Amazon, Brazil, under climate change and technological development. Agricultural Systems, 177, 102707. https://doi. org/10.1016/j.agsy.2019.102707

Justino, L. F., Alves Júnior, J., Battisti, R., Heinemann, A. B., Leite, C. V., Evangelista, A. W. P. and Casaroli, D. (2019). Assessment of economic returns by using a central pivot system to irrigate common beans during the rainfed season in Central Brazil. Agricultural Water Management, 224, 105749. https://doi.org/10.1016/j.agwat.2019.105749

La Menza, N. C., Monzon, J. P., Specht, J. E. and Grassini, P. (2017). Is soybean yield limited by nitrogen supply? Field Crops Research, 213, 204-212. https://doi.org/10.1016/J.FCR.2017.08.009

Lobell, D. B., Cassman, K. G. and Field, C. B. (2009). Crop Yield Gaps: Their Importance, Magnitudes, and Causes. Annual Review of Environment and Resources, 34, 179-204. https://doi.org/10.1146/annurev.environ.041008.093740

Mason, M. L. T., Tabing, B. L. C., Yamamoto, A. and Saeki, Y. (2018). Influence of flooding and soil properties on the genetic diversity and distribution of indigenous soybean-nodulating bradyrhizobia in the Philippines. Helion, 4, e00921. https://doi.org/10.1016/j. heliyon.2018.e00921

Merlos, F. A., Monzon, J. P., Mercau, J. L., Taboada, M., Andrade, F. H., Hall, A. J., Jobbagy, E., Cassman, K. G. and Grassini, P. (2015). Potential for crop production increase in Argentina through closure of existing yield gaps. Field Crop Research, 184, 145-154. https:// doi.org/10.1016/j.fcr.2015.10.001

Monteiro, L. A., Sentelhas, P. C. and Piedade, S. M. S. (2014). Dias trabalháveis para o manejo do solo em função da chuva e da disponibilidade hídrica do solo em diferentes regiões brasileiras. Revista Ambiente \& Água, 9, 459-475. https://doi.org/10.4136/ambi-agua.1389

Nóia Junior, R. S. and Sentelhas, P. C. (2019). Soybean-maize succession in Brazil: Impacts of sowing dates on climate variability, yields and economic profitability. European Journal of Agronomy, 103, 140-151. https://doi.org/10.1016/j.eja.2018.12.008

Pereira, A. R., Angelocci, L. R. and Sentelhas, P. C. (2002). Agrometeorologia: fundamentos e aplicações práticas. Guaíba: Agropecuária.

Pilau, F. G., Battisti, R. and Dalmago, G. A. (2018). Requerimento de irrigação suplementar e eficiência climática para a cultura da soja no Rio Grande do Sul. Agrometeoros, 26, 317-325. https://doi.org/10.31062/agrom.v26i2.26392 
Radin, B., Schönhofen, A. and Tazzo, I. F. (2017). Impacto da quantidade e frequência de chuva no rendimento da soja. Agrometeoros, 25, 19-26. https://doi.org/10.31062/agrom.v25i1.26263

Sentelhas, P. C., Battisti, R., Câmara, G. M. S., Farias, J. R. B., Hampf, A. C. and Nendel, C. (2015). The soybean yield gap in Brazil magnitude, causes and possible solutions for sustainable production. The Journal of Agricultural Science, 153, 1394-1411. https://doi. org/10.1017/S0021859615000313

Tagliapietra, E. L., Streck, N. A., Rocha, T. S. M., Richter, G. L., Silva, M. R., Cera, J. C., Guedes, J. V. C. and Zanon, A. J. (2018). Optimum Leaf Area Index to Reach Soybean Yield Potential in Subtropical Environment. Agronomy Journal, 110, 932-938. https://doi.org/10.2134/ agronj2017.09.0523

Teixeira, W. W. R., Battisti, R., Sentelhas, P. C., Moraes, M. F. and Oliveira Junior, A. (2019). Uncertainty assessment of soya bean yield gaps using DSSAT-CSM-CROPGRO-Soybean calibrated by cultivar maturity groups. Journal of Agronomy and Crop Science, 205, 533544. https://doi.org/10.1111/jac.12343

Thornthwaite, C. W. and Mather, J. R. (1955). The water balance. New Jersey: Drexel Institute of Technology. Climatology, 8.

van Ittersum, M. K., Cassman, K. G., Grassini, P., Wolf, J., Tittonell, P. and Hochman, Z. (2013). Yield gap analysis with local to global relevance - A review. Field Crops Research, 143, 4-17. https://doi.org/10.1016/j.fcr.2012.09.009

Wu, W., Yu, Q., You, L., Chen, K., Tang, H. and Liu, J. (2018). Global cropping intensity gaps: Increasing food production without cropland expansion. Land Use Policy, 76, 515-525. https://doi.org/10.1016/j.landusepol.2018.02.032

Xavier, A. C., King, C. W. and Scanlon, B. R. (2015). Daily gridded meteorological variables in Brazil (1980-2013). International Journal of Climatology, 36, 2644-2659. https://doi.org/10.1002/joc.4518

Zanon, A. J., Winck, J. E. M., Streck, N. A., Rocha, T. S. M., Cera, J. C., Richter, G. L., Lago, I., Santos, P. M., Maciel, L. R., Guedes, J. V. C. and Marchesan, E. (2015). Desenvolvimento de cultivares de soja em função do grupo de maturação e tipo de crescimento em terras altas e terras baixas. Bragantia, 74, 400-411. https://doi.org/10.1590/1678-4499.0043 